\title{
Patterns of enzymatic activity of cell wall-modifying enzymes during growth and ripening of apples
}

\author{
Luis F. Goulao ${ }^{\mathrm{a}}$, João Santos ${ }^{\mathrm{b}}$, Isabel de Sousa ${ }^{\mathrm{b}}$, Cristina M. Oliveira ${ }^{\mathrm{a}, *}$ \\ a Secção de Horticultura, Departamento de Produção Agrícola e Animal, Instituto Superior de Agronomia, Tapada da Ajuda, $1349-017$ Lisboa, Portugal \\ b Secção de Ciência e Tecnologia de Alimentos, Departamento de Engenharia Agro-Indústrial e Agronomia Tropical, Instituto Superior de Agronomia, \\ Tapada da Ajuda, 1349-017 Lisboa, Portugal
}

Received 26 June 2006; accepted 14 October 2006

\section{Abstract}

Fruit softening is thought to result from extensive cell wall modifications that occur during ripening. These modifications are the result, at least in part, of the activity of members of cell wall-modifying enzymes from the same families involved in the cell wall loosening which promote tissue extension and growth. In this work, the activities of a set of pectolytic and non-pectolytic cell wall-modifying enzymes, namely polygalacturonase (PG; endo-and exo-acting), pectin methylesterase (PME), pectate lyase (PL), $\beta$-galactosidase ( $\beta$-Gal), $\alpha$-L-arabinofuranosidase (AFase), endo-1,4- $\beta$-glucanase (EGase), xyloglucan endotransglycosylase (XET) and expansin, were monitored during growth and ripening of 'Mondial Gala' apple (Malus $\times$ domestica Borkh.) fruit. After optimisation of extraction protocols and standard activity assays, activity could be detected in all the assays, except for endo-PG. The overall results suggest that fruit growth and ripening are possibly coordinated by members of the same families of cell wall-modifying enzymes, although different isoforms may be involved in distinct developmental processes. Based on the trend of total activity measured in vitro using equal amounts of protein per developmental stage, the role of EGase seems to be more prominent during growth than during ripening, and XET activity is most important only after the fruit stopped growing and is maintained throughout ripening. $\beta$-Gal and AFase activities increased after harvest as the fruit became over-ripe. On the other hand, exo-PG, $\mathrm{PL}$ and expansin activities increase from that in unripe fruit to fruit at harvest but are maintained at similar levels thereafter, throughout the over-ripe stages. The patterns of activity observed are discussed in relation to published information about ripening of apples and to results reported using other species.

(c) 2006 Elsevier B.V. All rights reserved.

Keywords: Cell wall; Enzymatic activity; Fruit development; Fruit ripening; Fruit softening; Malus $\times$ domestica Borkh

\section{Introduction}

Selective modification of the cell wall architecture is associated with almost every stage of development. It is an integral part of cellular growth, but it also occurs in several non-growing organs in events such as seed germination, anther dehiscence, penetration of pollen tubes in the pistils, abscission of leaves, flowers and fruit, development of intercellular spaces (e.g. aerenchyma), and fruit ripening. Fruit ripening involves changes in the composition and organization of pectin, hemicellulose and cellulose polysaccharides of the cell wall, which takes place as a coordinated series

\footnotetext{
* Corresponding author. Tel.: +3512136534 53; fax: +351213623262. E-mail address: crismoniz@isa.utl.pt (C.M. Oliveira).
}

of assembly and disassembly steps. Although growth has ceased, selective disassembly of the cell wall components and cell-to-cell separation is very pronounced during fruit ripening and is thought to be a key ripening-associated metabolic event that determines the timing and extent of loss of cell adhesion, which leads to fruit softening. The plant cell wall is a highly complex and dynamic structure composed of a network of hemicelluloses linked to cellulose microfibrils, embedded in a matrix of pectic polymers and other less abundant compounds, like phenols, structural proteins and enzymes (Brett and Waldron, 1996). Due to the nature of the polymers, a large number of linkages exist within the cell wall, maintaining and reinforcing its structure, thus various families of enzymes and their different isoforms are suggested to affect these processes. It has been proposed that 
among the principal enzymes that act on the linkages between cell wall polymers are polygalacturonases (PG) (endo- and exo-), pectin methylesterases (PME), pectate lyases (PL), $\beta$ galactosidases ( $\beta$-Gal), $\alpha$-L-arabinofuranosidases (AFase), endo-1,4- $\beta$-glucanases (EGase), xyloglucan endotransglycosylase/hydrolases (XTH) and expansins. Although the same enzymes are believed to participate in different developmental processes, each particular event is probably regulated by the activity or by the selective regulation of different isoforms of the same enzyme, acting sequentially or overlapping. In addition, a single enzyme does not seem to be the uniquely responsible for the disassembly of the cell wall, which results in softening, so the action of these enzymes should be investigated collectively. With the advent of molecular biology, a number of genes have been recently identified, and a role for some enzyme families in fruit softening has been proposed, based on the correlation of mRNA accumulation and a given physiological stage or phenotype. This molecular information has been used to generate antisense or overexpressing transformants aimed to assess the physiological role of each enzyme. The results from genetic transformation supports the role of enzymes like expansins (Brummell et al., 1999), PLs (Jiménez-Bermúdez et al., 2002), and at least one $\beta$ Gal isoform (TBG4; Smith et al., 2002) in fruit softening, as antisense fruit proved to be firmer than controls and fruit over-expressing these transcripts showed a larger extent of softening. Nonetheless, a fruit that fails to soften has not been obtained by individual suppression of any transcript or activity. On the other hand, down-regulation of PG (Smith et al., 1988), PME (Tieman and Handa, 1994) or some $\beta-G a l$ isoforms (reviewed in Smith et al., 2002) resulted in fruit with no significant differences in pulp firmness, despite some characteristics of the cell wall having been modified. The combined results illustrate that individual enzymes are not sufficient to produce an effect on fruit softening, so it has become evident that possible concomitant action of several isoforms and post-transcriptional regulatory events may be involved. In fact, although changes in levels of mRNA may predict changes in enzyme levels, the transcripts may not necessarily be translated and proteins detected in immunoassays may not necessarily be suitably modified by post-translational mechanisms to be fully active. Furthermore, the role of each enzyme cannot be explained by studying a single isoform since the presence of several isoforms, with distinct patterns of expression, may mask the total activity in a given developmental stage. Also, the presence of mRNA transcripts encoding for a specific isoform cannot be directly correlated to the resultant total enzymatic activity, due to different transcription rates. For example, from the seven expansin (FaEXP 1-7) mRNAs expressed during strawberry (Fragaria ananassa Duch.) fruit development, FaEXP3, which is expressed in small green fruit and in ripe fruit, is transcribed at much lower levels (1000-fold) than the other expansin mRNAs (Harrison et al., 2001). For these reasons, assays for monitoring the changes in the activity during the development of the fruit are needed to complement the studies on genetic expression.
In apples (Malus $\times$ domestica Borkh.), the activity of several cell wall-modifying enzymes has been reported and for some families, the activity fluctuations have been measured during fruit growth (Vincken et al., 1998) or ripening (reviewed by Johnston et al., 2002), although no work has investigated a set of enzymatic activities together using the same biological material. Furthermore, the ripening behaviour has been studied using fruit held under cold storage. The objective of this study was to determine the temporal patterns of activity of enzymes that have been implicated in cell wall modifications, to gain an insight into the changes in each activity during the complete development process; from fruit-set to over-ripe fruit.

\section{Materials and methods}

\subsection{Plant materials}

Apples (Malus $\times$ domestica Borkh cv. Mondial Gala) were obtained from trees grown at the experimental orchard of the Instituto Superior de Agronomia, Lisboa, Portugal, during two growing seasons. The fruit used were classified and assigned to classes according to their physiological stage, based on their time from anthesis or from harvest, size, skin colour, seed maturation and pulp firmness as: fruit set (stage 1), growing fruit (stage 2), unripe expanded fruit (stage 3), fruit at harvest (stage 4) and over-ripe fruit (stage 5). In all cases, samples were harvested, immediately frozen in liquid nitrogen and stored at $-80{ }^{\circ} \mathrm{C}$ until extraction of proteins. Fruit at stages 1 and 2 were frozen and assayed with skin, whilst fruit from stages $3-5$ were peeled and cut in small slices immediately before freezing. Fruit diameter was measured at the equatorial section using a vernier calliper. Seed maturation was assessed visually and colour of the fruit skin was accessed visually and measured using a colorimeter (Minolta Meter CR-300). Ground colour was expressed as the hue angle value in the Hunter scale (McGuire, 1992). Firmness of the pulp was determined using a Texture Analyser (TAXT2, Stable Micro Systems Texture Technologies, Scarsdale, NY) fitted with an $11 \mathrm{~mm}$ diameter flat probe. Peeled flat areas of the fruit were compressed $8 \mathrm{~mm}$ at a test speed of $1 \mathrm{~mm} \mathrm{~s}^{-1}$. The compression force for each fruit was measured three times and the average of the maximum force necessary for the compression was used to define firmness. After the definition of developmental classes, based on the statistical analysis of 30 fruit, more than 60 fruit from each developmental stage and growing season were attributed to the classes defined. Sliced (stages 3, 4 and 5) or intact (stages 1 and 2) fruit were stored at $-80^{\circ} \mathrm{C}$ in bulks of mixed fruit from the same developmental stage. For extraction of proteins, $10 \mathrm{~g}$ samples of these fruit bulks were used per enzyme assay and per sample. For each enzyme activity, three independent assays were conducted per season (giving six replications). For expansin assays, four replications were made due to the high concentration of proteins required to detected activity 
under the conditions used. In viscosimetric and spectrophotometric assays, three readings were done per sample.

\subsection{Statistical analysis}

Single-factor (for fruit diameter, ground colour, and firmness), or two-way (for enzyme assay results) ANOVA analyses of were conducted using the Microsoft Office Excel 2003 for Windows software. Means were compared using the Fisher's least significant difference (LSD) post-test at $P \leq 0.01$ with the SPSS (Version 12.0) software.

\subsection{Protein extraction}

All operations were conducted at $2{ }^{\circ} \mathrm{C}$. Total crude protein extracts were prepared starting with approximately $10 \mathrm{~g}$ of composite samples of fruit tissue at each developmental stage. The tissues were ground into fine powder in liquid nitrogen, using a mortar and pestle, and washed three times in cold acetone. Dry acetone powders were homogenized in $25 \mathrm{ml}$ extraction buffer $(200 \mathrm{mM}$ sodium phosphate buffer $\mathrm{pH}$ 8.0 containing $5 \mathrm{mM}$ EDTA and $5 \mathrm{mM}$ DTT (dithiothreitol)). One millilitre of $250 \mathrm{mM}$ PMSF (phenylmethylsulphonylfluoride) was immediately added, and the homogenates were incubated at $2{ }^{\circ} \mathrm{C}$ for $30-60 \mathrm{~min}$, with occasional mixing. The $\mathrm{pH}$ of each sample was checked with test paper and confirmed to be between 6 and 7 for all samples. The suspensions were then centrifuged at $20,000 \times g$ for $1 \mathrm{~h}$ at $4{ }^{\circ} \mathrm{C}$ and the supernatants were filtered through cheesecloth. Finally, the extracts were desalted using Sephadex G-25 medium in PD-10 columns (Amersham Biosciences, Uppsala, Sweden) according to the manufacturer's instructions, frozen at $-80^{\circ} \mathrm{C}$, and lyophilised over 2 days. For each activity assay, lyophilised powders were resuspended in a maximum of $1 \mathrm{~mL}$ of the corresponding assay buffer and immediately assayed. Protein contents were measured using the dyebinding method of Bradford (1976) using BSA (bovine serum albumin) as standard.

\subsection{Enzyme activity assays}

For each enzyme activity assay, both lyophilised powders and substrates were resuspended in the corresponding assay buffer, to obtain high concentrations of the proteins in the reaction mixtures. For the activity of pectolytic enzymes that require calcium (PG and PL), the amount of calcium chloride necessary to achieve a $2 \mathrm{mM}$ final concentration in the mixtures was added to a buffer aliquot used to resuspend the protein lyophilised extracts and was not included in the buffer used to dissolve substrates to prevent formation of insoluble calcium-polygalacturonate complexes (Collmer et al., 1988). For those reasons, small modifications were introduced in previously published tests for each enzyme to be assayed. All assays were conducted based on equal amounts of total protein for each developing stage. All assays were conducted in six replicates (from two growing seasons), except for expansin (four replicates, due to the high protein concentration required to detect activity). Negative control reactions were always included, consisting of denatured proteins boiled for $10 \mathrm{~min}$ in $10 \% \mathrm{SDS}$. The Unicam UV-vis spectrophotometer UV4 and Vision software (Ver. 3.31) were used, whenever colorimetric determinations were involved.

\subsubsection{Endo- and exo-polygalacturonase activity}

Endo-PG activity was assayed by a viscosimetric method. Several pectic substrates with distinct degrees of esterification and from different plant sources were tested, including sodium polypectate from citrus fruit (Sigma), polygalacturonic acid from orange (Sigma), citrus pectin $90 \%$ esterified (Sigma) and apple pectin 70-75\% esterified (Fluka). Reaction mixtures containing $250 \mu \mathrm{L} 2.0 \%(\mathrm{w} / \mathrm{v})$ each substrate (prepared fresh for the assay) and $150 \mu \mathrm{L}$ protein extract (48 $\mu$ g per sample), both in $50 \mathrm{mM}$ sodium acetate buffer $\mathrm{pH}$ 4.5. Calcium chloride concentration in the final mixture was set up to $2 \mathrm{mM}$ as described above. Initial viscosity was determined by measuring the time taken for the movement of the mixture through the 0 and the $0.05 \mathrm{ml}$ marks of a $0.1 \mathrm{~mL}$ glass pipette fixed in a vertical position. Three readings were measured for each replicate using a stopwatch. The mixtures were then incubated for 4 and $24 \mathrm{~h}$ at $37^{\circ} \mathrm{C}$ with shaking. After a 15 min equilibration period at $24^{\circ} \mathrm{C}$, the viscosity of the mixture was measured again as described. Exo-PG activity was determined using a reducing sugar assay according to the 2cyanoacetamide method described by Gross (1982). After $5 \mathrm{~h}$ at $30^{\circ} \mathrm{C}$, the formation of reducing groups was estimated by measuring the absorbance at $246 \mathrm{~nm}$ and comparison with a calibration curve obtained using D-galacturonic acid (Sigma) as standard.

\subsubsection{Pectin methylesterase activity}

PME was assayed based on the spectrophotometric procedure of Hagerman and Austin (1986). Changes in the absorbance were monitored at $616 \mathrm{~nm}$ for $20 \mathrm{~min}$ in a runassay. The analysis of the graphics showed some perturbations in the curve during the first $60 \mathrm{~s}$ of the assay, probably due to the mixing of the proteins and diffusion of the colour generated by newly formed products in the solution. Therefore, the results were expressed as the difference in measured absorbance readings between $15 \mathrm{~min}$ and $60 \mathrm{~s}$, since in this region the curves showed a near-linear decrease.

\subsubsection{Pectate lyase activity}

PL activity was estimated at $540 \mathrm{~nm}$ using the thiobarbituric acid method (Weissbach and Hurwitz, 1959), at $37^{\circ} \mathrm{C}$ for $18 \mathrm{~h}$, in $100 \mathrm{mM}$ Tris- $\mathrm{HCl}$ buffer $\mathrm{pH} 9.0$ containing $2.0 \mathrm{mM}$ calcium chloride and $130 \mu \mathrm{g}$ of total extracted proteins. It should be noted that using the standard method described by Collmer et al. (1988), no activity was detected, presumably due to the presence of interfering substances in the extracts which result in high absorption at $232 \mathrm{~nm}$. The same has also been observed by others (Pilatzke-Wunderlich and Nessler, 2001; Payasi et al., 2004). ripening of apples, Postharvest Biol. Technol. (2006), doi:10.1016/j.postharvbio.2006.10.002 


\subsection{4. $\beta$-galactosidase and $\alpha$-L-arabinofuranosidase activity}

$\beta-G a l$ and AFase activities were assayed according to Pressey (1983), by measuring the hydrolysis of $p$ nitrophenyl- $\beta$-D-galactopyranoside or $p$-nitrophenyl- $\beta$-Darabinofuranoside, in $50 \mathrm{mM}$ sodium acetate $\mathrm{pH} 4.0$ or $\mathrm{pH}$ 5.0 , respectively. The released $p$-nitrophenol was measured spectrophotometrically at $415 \mathrm{~nm}$, after incubations of $15 \mathrm{~min}$ and $3 \mathrm{~h}$ at $37^{\circ} \mathrm{C}$, respectively. Activity was reported as the amount of $p$-nitrophenyl glycoside released according to a comparison with a standard curve constructed using $p$ nitrophenol (Sigma).

\subsubsection{Endo-1,4- $\beta$-glucanase activity}

EGase activity was measured by the change in viscosity of a solution containing CMC (Durbin and Lewis, 1988). One hundred millilitre of enzyme extract were added to $350 \mu \mathrm{l}$ of a $1.5 \%(w / v)$ CMC (medium viscosity, Sigma) solution in $20 \mathrm{mM}$ phosphate buffer $\mathrm{pH}$ 6.0. Each sample contained $55 \mu \mathrm{g}$ total proteins. Viscosimetry readings were taken at time 0 and after $6 \mathrm{~h}$, according to the procedure described in the endo-PG assay. Activity was reported as the percentage of viscosity reduction after the assay period, with respect to time zero.

\subsubsection{Xyloglucan endotransglycosylase activity}

XET activity was determined according to the semiquantitative blot assay described by Fry (1997), for $1 \mathrm{~h}$ at $26^{\circ} \mathrm{C}$ in $50 \mathrm{mM}$ phthalate buffer $\mathrm{pH} 5.5$ and $11 \mu \mathrm{g}$ protein. The relative density of each spot was calculated using the 'Scion Image (Version beta 4.0.2) for Windows' software and the activity was reported as the percentage of the maximum reading.

\subsubsection{Expansin activity}

Activity of expansins was assayed by a stress-relaxation test according to Cosgrove (1989) with some modifications, using a TA-XT2 Texture Analyser fitted with tensile grips. A custom-made plastic cuvette was adapted to the lower tensile grip to allow the wall specimens to be submerged in the sample solution during the assays. Seeds of Cucumis sativus L. cv. Burpee Pickler were grown at $28^{\circ} \mathrm{C}$ in the dark, in a humidified environment. The active growing region of the hypocotyls (cell wall specimens) was excised, frozen at $-20^{\circ} \mathrm{C}$, thawed, and the cuticle was abraded with carborundum slurry. Endogenous enzymes were inactivated by boiling the hypocotyls in water, prior to the assays. After equilibration at room temperature, cell fluids were removed by pressing the hypocotyls between two microscope slides. The wall specimens were clamped between two grips separated $5 \mathrm{~mm}$ in $50 \mathrm{mM}$ sodium acetate $\mathrm{pH} 4.5$ buffer. A constant force of $20 \mathrm{~g}$ was applied for $30 \mathrm{~min}$ to minimize intrinsic variations of the cell wall specimens. After that period, the buffer was completely removed and replaced with $300 \mu \mathrm{L}$ of protein samples $(1.25 \mathrm{mg} / \mathrm{mL}$ assay buffer $)$ and, after applying a $20 \mathrm{~g}$ initial force, the subsequent force required to maintain the distance between clamps was recorded for $20 \mathrm{~min}$ at 25 points per second. All assays were performed at $24^{\circ} \mathrm{C}$. The stress relaxation spectrum of each sample was obtained as a function of $\mathrm{d}($ Force $(\mathrm{g})) / \mathrm{d}\left(\log _{10} t(\mathrm{~s})\right)$ with respect to $\log _{10} t(\mathrm{~s})$ (Cosgrove, 1996). Estimates of total expansin activity were based on the force necessary to maintain the cell wall specimen distance at the end of the assay. Activity was reported after subtracting the force measured to the negative control values.

\subsection{Establishment and validation of developmental stages in apple}

Due to the high number of studies conducted in tomato (Lycopersicon esculentum Mill.) (taken as a model for climacteric fruit ripening) and strawberry (used as a model development and maturation have already been established for these species. Hence, direct comparison of the results obtained from different research groups can be undertaken. In apple this information is not available. For that reason, a preliminary assay was conducted to define suitable fruit developmental stages to be used in the subsequent analyses. For that, the behaviour of fruit growing and ripening was investigated from fruit set to over-ripe stages. Fruit size, skin colour, seed maturation and pulp firmness were quantified (Fig. 1), and based on the results obtained, five stages of development and ripening are proposed (Table 1). As shown in Fig. 1, the growth curve obtained for 'Mondial Gala' apples is in accordance with the typical growing pattern of pome fruit (Peña and Carpita, 2004). The diameter of the fruit was used as the criteria to classify the fruit through until commercial maturity. During the growth of apples, fruit classified as stage 1 were collected from 35 to 45 days post-anthesis (dpa), which corresponds to the period of fruit set and predominant cell division (Gillaspy et al., 1993). All fruit attributed to this stage were of between 15 and $25 \mathrm{~mm}$ diameter (Table 1).

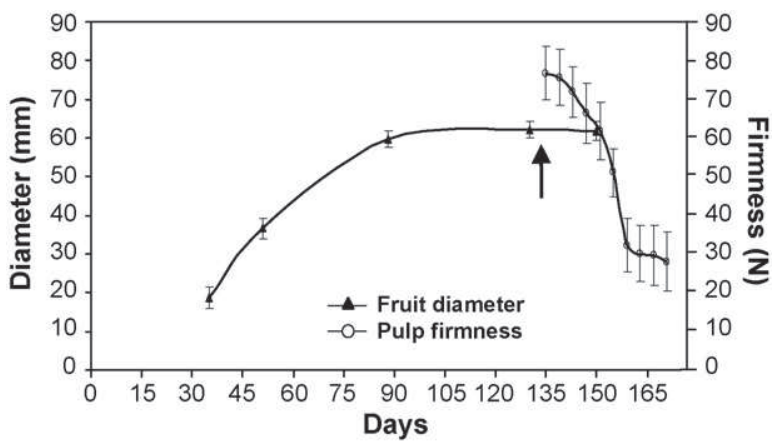

Fig. 1. Growth, development and ripening behaviour of 'Mondial Gala' apples. Values and vertical bars indicate the mean and S.D. of measurements for 30 fruit per observation. The arrow shows the date of harvest.

\section{Results} for non-climacteric fruit ripening), well established stages of ripening of apples, Postharvest Biol. Technol. (2006), doi:10.1016/j.postharvbio.2006.10.002 
Table 1

Description of the criteria used to classify the fruit (bold) and the measured characteristics by growing season

\begin{tabular}{|c|c|c|c|c|c|}
\hline Developmental stage & (1) Fruit set & (2) Active growing & (3) Unripe; expanded & (4) Harvest & (5) Overripe \\
\hline $\mathbf{d p a}^{\mathrm{a}} / \mathbf{d p h}^{\mathrm{b}}$ (days) & $35-45^{\mathrm{a}}$ & $60-70^{\mathrm{a}}$ & $90-100^{a}$ & $135-140^{\mathrm{a}}$ & $21-30^{b}$ \\
\hline Growing season 1 & 41 & 67 & 95 & 137 & 25 \\
\hline Growing season 2 & 39 & 65 & 94 & 136 & 25 \\
\hline Diameter (mm) & $15-25$ & $32-40$ & - & - & - \\
\hline Growing season 1 & $17.4 \pm 2.5 \mathrm{a}$ & $37.1 \pm 2.4 \mathrm{~b}$ & $61.6 \pm 2.3 \mathrm{c}$ & $62.3 \pm 2.3 c$ & $61.6 \pm 2.8 \mathrm{c}$ \\
\hline Growing season 2 & $18.5 \pm 3.0 \mathrm{a}$ & $36.8 \pm 1.9 \mathrm{~b}$ & $60.2 \pm 2.4 \mathrm{c}$ & $61.4 \pm 2.1 \mathrm{c}$ & $62.7 \pm 3.0 \mathrm{c}$ \\
\hline Mature seeds (\%) & - & - & 30-70 & 90-100 & \\
\hline Growing season 1 & & & $45.7 \pm 9.1$ & 100 & \\
\hline Growing season 2 & & & $48.4 \pm 8.7$ & 100 & \\
\hline Skin colour (\% red) & - & - & $<\mathbf{1 / 3}$ & About $2 / 3$ & \\
\hline Growing season 1 & & & $<1 / 3$ & About $2 / 3$ & \\
\hline Growing season 2 & & & $<1 / 3$ & About $2 / 3$ & \\
\hline Ground hue $\left(^{\circ}\right)$ & - & - & $106-115$ & $100-105$ & $<105$ \\
\hline Growing season 1 & & & $114.2 \pm 9.7 \mathrm{a}$ & $103.6 \pm 8.3 \mathrm{~b}$ & $95.7 \pm 7.2 \mathrm{c}$ \\
\hline Growing season 2 & & & $112.3 \pm 9.1 \mathrm{a}$ & $102.1 \pm 7.9 \mathrm{~b}$ & $94.1 \pm 8.3 \mathrm{c}$ \\
\hline Growing season 1 & & & $121.6 \pm 7.9 \mathrm{a}$ & $76.2 \pm 9.1 \mathrm{~b}$ & $32.2 \pm 6.3 \mathrm{~d}$ \\
\hline Growing season 2 & & & $129.7 \pm 8.1 \mathrm{a}$ & $78.8 \pm 8.3 b$ & $31.6 \pm 7.1 \mathrm{~d}$ \\
\hline
\end{tabular}

Values are the average \pm S.D. of 30 representative samples and the letters represent statistical significance at $1 \%$.

a dpa-days post-anthesis.

b dph-days post-harvest.

Between 60 and 70 dpa, the development of apples is based mainly on cell growth (Gillaspy et al., 1993). During this period, fruit with a diameter between 32 and $40 \mathrm{~mm}$ were sampled and classified as stage 2 . Around 90-100 dpa, fruit stopped growing, as revealed by media comparison analysis, but they were still unripe, based on their skin and seed colours (Table 1). These fruit were assigned to stage 3. At this stage, firmness of the pulp started to be assessed at regular periods in order to define the date of harvest, based on commercial maturity criteria. Harvest was initiated when fruit reached 80-90 N, as measured in the field using the Magness-Taylor test. Visual observation of the ground skin colour supported the decision for harvesting. Harvest was done around $135 \mathrm{dpa}$, which is in accordance with other studies with 'Gala' apples (Peña and Carpita, 2004). Harvested fruit were sampled for stage 4 and a set was allowed to ripe at $22^{\circ} \mathrm{C}$. The change in the firmness of the pulp measured with a texture analyser (Fig. 1) agrees with previous work (Johnston et al., 2001). Softening of several apple cultivars, including 'Gala', is triphasic at low storage temperatures, consisting of an initial slow softening phase, a rapid softening phase and a final slow softening phase, although above $12{ }^{\circ} \mathrm{C}$, the first phase is usually not present (Johnston et al., 2001). In the present study, however, this phase could be observed for a short period of time even at $22^{\circ} \mathrm{C}$. A possible explanation might reside in differences in fruit sampling at harvest, since in this work the firmness of each fruit studied was measured and the fruit were carefully selected according to the criteria described previously. Fruit with firmness out of the range defined were discarded. This contrasts with harvest for commercial purposes, in which fruit with mixed firmness values are collected together. Physiologically over-ripe fruit were considered to be those in the final phase of softening, with firmness below $40 \mathrm{~N}$, and were classified as stage 5 . However, it should be noted that fruit with firmness below $65 \mathrm{~N}$ are not accepted by the market.

\subsection{Protein extraction}

Apples are known to have characteristically low protein content, about $0.2 \%(\mathrm{w} / \mathrm{w})$ (Wu et al., 1993). In this work, a protocol for the extraction of total soluble proteins was adapted and optimised based on standard procedures (Deutscher, 1990), in order to be suitable for all the assays conducted. The protocol described in Section 2 allowed the best yields, with the highest activity (evaluated in preliminary assays after testing for $\beta$-Gal, EGase and XET activities in fruit at harvest) when compared with a large set of alternative protocols described in the literature (data not shown). The amount of protein extracted was low, but increased from fruit set to over-ripe fruit, ranging from $65.9 \pm 19.7 \mu \mathrm{g} \mathrm{g}^{-1}$ at fruit set to $334.6 \pm 64.8 \mu \mathrm{g} \mathrm{g}^{-1}$ in over-ripe fruit. This is probably the result from differences in the nature of the biological material such as increased water content and decreased cell wall material as the fruit mature, which results in more efficient solubilisation and extraction of the proteins, rather than a significant increase in the protein content of the fruit. According to Lay-Yee et al. (1990), the amount of protein extracted from apples is not significantly different between different ripening stages. Such facts must be considered carefully when the objective is to measure enzyme activities based on a fresh weight basis. The extracted proteins were analysed by conventional SDS-PAGE and the results suggest that the method employed for the extraction, desalting and concentration of the proteins was adequate and did not cause major degradation of the proteins (Supplementary Fig. 1). Moreover, the pattern of proteins obtained during fruit development suggests that the major differences in the protein 
composition occur at stage 3, when fruit stop growing (data not shown).

\subsection{Patterns of enzyme activity}

The levels of activity of the cell wall enzymes assayed show different patterns throughout the development and ripening of apples. Figs. 2 and 3 show the fluctuations of the activity of pectolytic and non-pectolytic cell wall-modifying enzymes respectively, using total protein extracts in five developmental stages. Pectolytic activity could be detected for all enzymes assayed, except for endo-PG, even using a viscosimetric assay, which is considered to be the most sensitive test available for monitoring the activity of this enzyme (Tagawa and Kaji, 1988). Moreover, high concentrations of extracted proteins and several substrates were used (see Section 2). Lack of endo-PG detectable activity during ripening was also reported in previous works in apples. According to several authors (Bartley, 1978; Abeles and Biles, 1991; Yoshioka et al., 1992), the increase in pectin solubility occurs without detectable activity of endo-PG, and only exo activity has been detected during ripening in this species (Bartley, 1978). The results obtained in all of the other assays show a general decrease to low levels in unripe, expanded fruit and a subsequent increase as the fruit ripens (Fig. 2). This evidence suggests the action of different isoforms during fruit growth and during ripening and softening. $\beta$-Gals and AFases are glycosidases that putatively act on the sugars that compose and decorate the side-chains of the polysaccharides. These enzyme families display an increased activity after commercial maturity, reaching its maximum in over-ripe fruit (Fig. 2D and E). This aspect is highly significant in the AFase assay. Exo-PG and PL activities were maintained at similar levels after harvest whilst PME activity decreased slightly from harvest to the over-ripe stage (Fig. 2A-C). All pectolytic enzymes displayed significant levels of activity during fruit growth. Whilst PL and AFase seemed to be more important at fruit set (with active cell division), exo-PG, PME and $\beta-G a l$ increased when the fruit are growing (during cell expansion). The pattern of activity of non-pectolytic enzymes is shown in Fig. 3. EGase activity was high at fruit set and decreased progressively during fruit development (Fig. 3A). This result de-emphasises the importance of this enzyme family in the ripening progress of apples, although its action seems to be necessary to promote growth of the fruit. XET activity is one of the two activities known of xyloglucan endotransglycosylase/hydrolase (XTH) enzymes. Only transglycosylase activity could be measured in this work using crude protein extracts. The hydrolytic activity derived from XTHs cannot be determined due to the presence of putatively interfering endoglucanases that can also act on hemicelluloses. Expansin activity was estimated using a stress-relaxation assay, which is assumed to be more specific for assessing expansin activity than the creep assay, using crude samples. From Figs. 3C and 4, it is clear that the highest activity occurred at fruit set and low activity was detected in unripe
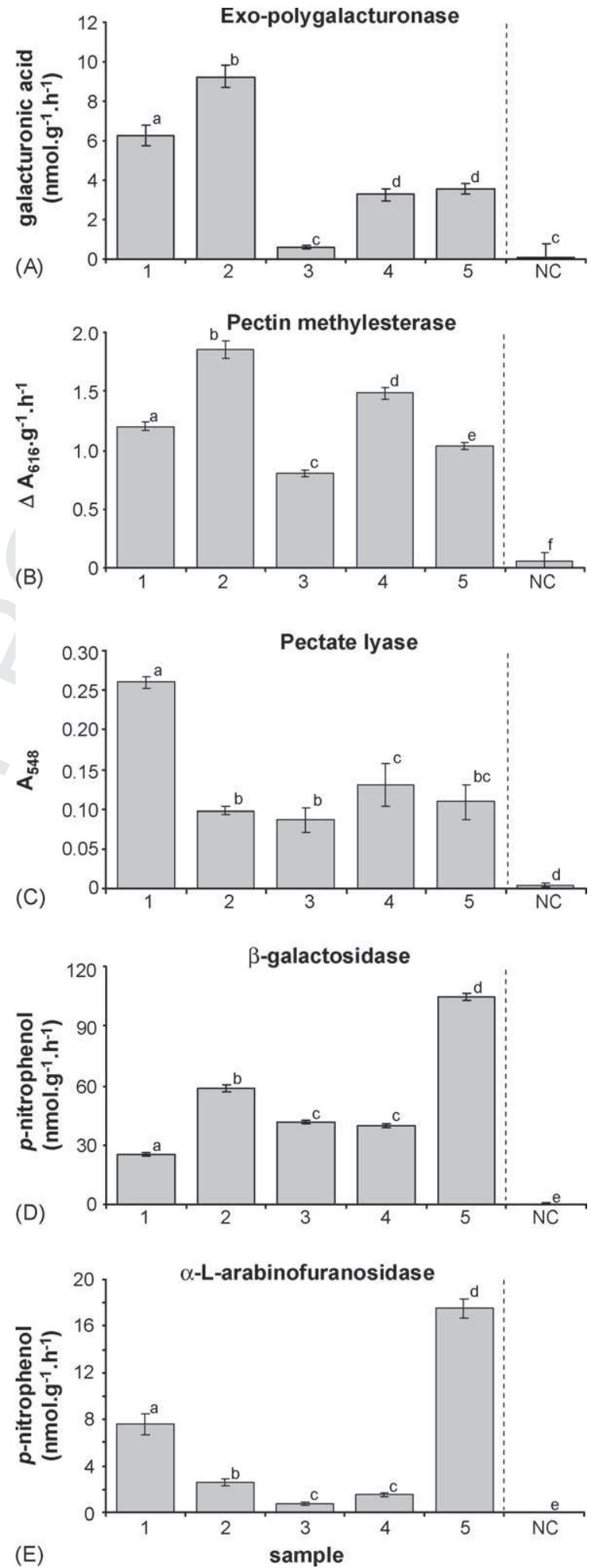

Fig. 2. Patterns of pectolytic enzymatic activities accessed during growth and ripening of 'Mondial Gala' apples using the assays described in Section 2. (1) Fruit-set; (2) growing fruit; (3) unripe, fully expanded fruit; (4) fruit at harvest; (5) over-ripe fruit; NC, negative control (boiled enzyme extract with $10 \%$ SDS). Values represent the mean \pm S.D. of six replicates per assay. Letters represent statistical significance at $1 \%$ 

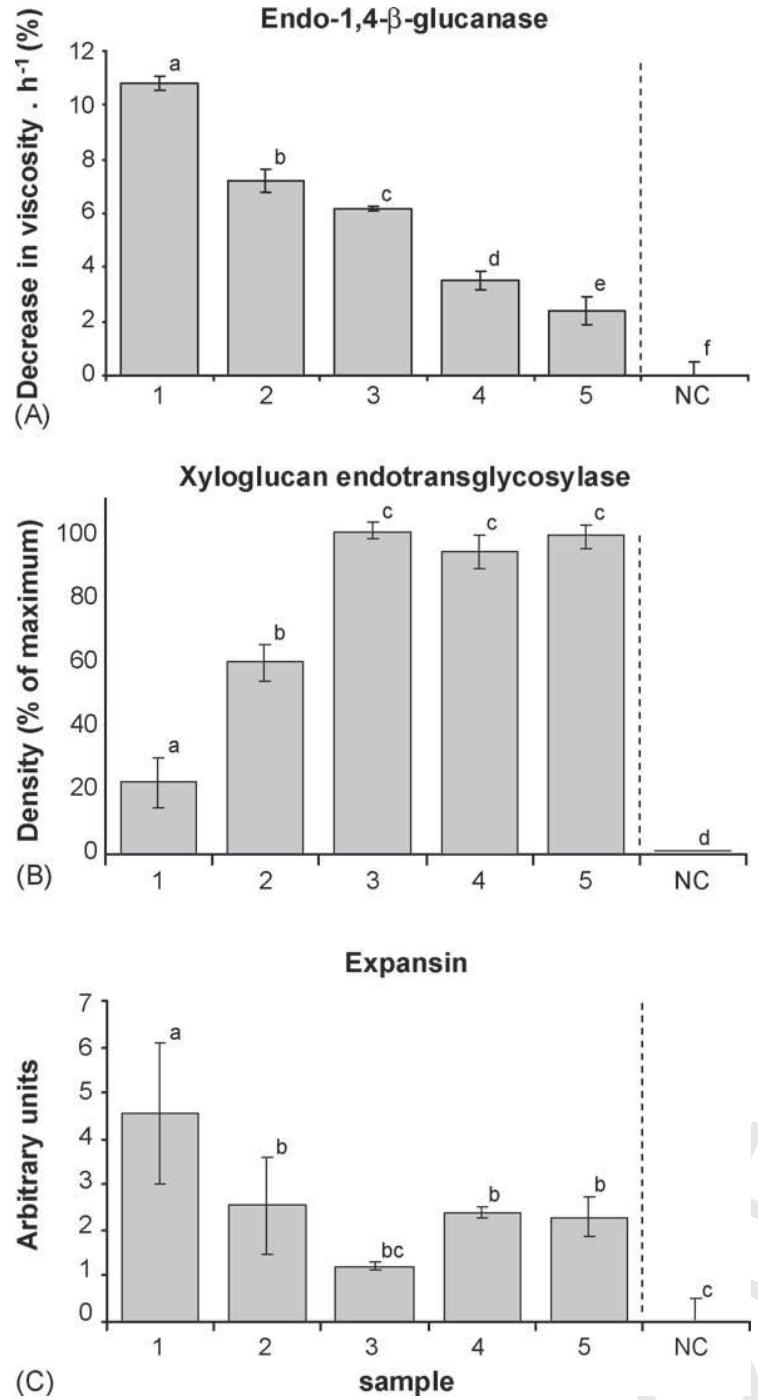

Fig. 3. Patterns of non-pectolytic enzymatic activities accessed during growth and ripening of 'Mondial Gala' apples using the assays described in Section 2. (1) Fruit-set; (2) growing fruit; (3) unripe, fully expanded fruit; (4) fruit at harvest; (5) over-ripe fruit; NC, negative control (boiled enzyme extract with $10 \%$ SDS). Values represent the mean \pm S.D. of six replicates per assay, except for the expansin assay in which $n=4$. Letters represent statistical significance at $1 \%$.

expanded fruit. There seemed to be similar levels of activity from harvest to the over-ripe stage. Interestingly, this pattern has some similarity with the pattern of enzyme activities of pectolytic enzymes. In this study, estimates of total activity attributed to expansin action were assumed to be correlated with the force necessary to maintain the cell wall specimen distance at the end of the assay, after subtracting the force measured from the negative control values. However, the analysis of each individual stress-relaxation profile is necessary to achieve more detailed information. Based on the observation of individual stress-relaxation profiles in different developmental stages (Fig. 4), a similar mode of action is suggested to occur from fruit set to unripe fully expanded fruit. However, the spectrum is considerably distinct in fruit

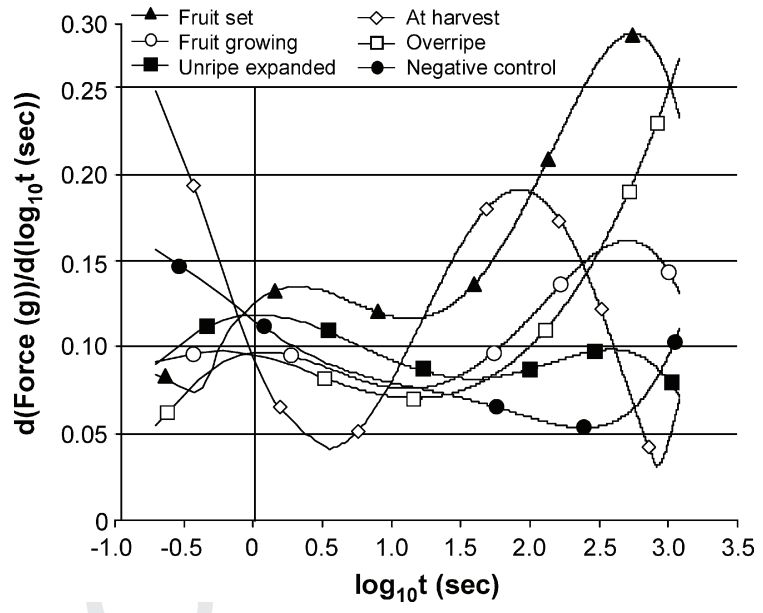

Fig. 4. Stress-relaxation spectra of specimens of inactivated cucumberhypocotyl cell walls incubated with crude protein extracts purified during 'Mondial Gala' apple growth and ripening. Relaxation in shown as the derivative of force $(\mathrm{g})$ with respect to $\log _{10}$ of time (s). The plots represent the average of four samples per developmental stage. Negative control stands for boiled enzyme extract with $10 \%$ SDS.

collected at harvest and in over-ripe fruit. This suggests that different isoforms can be involved in the process, or that they can be acting in distinct linkages between polysaccharides. Therefore, the difference in the spectrum obtained using fruit at harvest and over-ripe fruit should be considered together with the results shown in Fig. 3C, which indicates similar activity levels in both developmental stages. The overall results provide a general picture of the activity fluctuations of the most studied cell wall-modifying enzymes from apple fruit set to the over-ripe stage. Since all activities were estimated using the same biological material, their role in the development and ripening of apples can be collectively discussed.

\section{Discussion}

Diverse structural changes in pectins, hemicelluloses and cellulose together may be responsible for the alteration of cell wall structure that occurs during fruit ripening (Huber, 1983; Seymour et al., 1990). Depending on the fruit species, different modifications may occur and to different extents. Although pectic solubilisation is considered to be a universal feature of pectin modification, depolymerisation of pectins seems to occur additionally in some species like avocado (Huber and O'Donoghue, 1993), peach (Orr and Brady, 1993), persimmon (Cutillas-Iturralde et al., 1993) or tomato (Sakurai and Nevins, 1993; Brummell and Labavitch, 1997), whilst it is absent in others, including apple (Yoshioka et al., 1992; Redgwell et al., 1997a). Similarly, apples soften without detectable depolymerisation of hemicelluloses (Bartley, 1976; Siddiqui et al., 1996; Percy et al., 1997), whilst in other species, depolymerisation of these compounds appears to occur (e.g. MacRae and Redgwell, 1992; Maclachlan and 
Brady, 1994; Sakurai and Nevins, 1997; Barnavon et al., 2000). Loss of neutral sugars from side-chains of pectins is also a universal event that occurs concomitantly with ripening but depending on the species, different sugars are lost (Gross and Sams, 1984). Since differences exist between different species, species other than the fruit model tomato should be investigated.

In apple, the concentration of water-soluble polyuronides increases (Knee, 1978a; Siddiqui et al., 1996) but those of EDTA and chloridric acid- $(\mathrm{HCl})$ soluble polyuronides decrease during softening (Yoshioka et al., 1992). Siddiqui et al. (1996) suggest that pectin solubilisation may result from enzymatic cleavage of linkages between pectin and other cell wall components. The activity of enzymes like exo-PG, $\beta$ Gal or AFase may be responsible for pectin solubilisation. The present results show an increase in these enzymes with the onset of ripening. Detection of exo-PG activity in ripening apples is in accordance with Bartley (1978).

Loss of firmness has been associated with a significant decrease in the galactose content of the cell wall, associated with $\beta$-Gal activity (Bartley, 1974; Ross et al., 1994). Apple $\beta$-Gal showing activity against native substrates have been purified and partially characterised from ripe apples (Dick et al., 1990; Ross et al., 1994; Yoshioka et al., 1995) and a cDNA clone characterised (Ross et al., 1994). In this work, a gross change in $\beta$-Gal activity during apple growth and ripening was not observed, although it had its lowest level at fruit set, and its highest in over-ripe fruit. This pattern is probably the result of the action of more than one isoform. Four $\beta$-Gal activities (GA-I-IV) were detected in cell wall extracts from apples stored at $0{ }^{\circ} \mathrm{C}$ for 5 months (Yoshioka et al., 1995). The activity of GA-I is undetectable at harvest, and as the fruit ripen, and is the only one of the four isoenzymes that increases after harvest, whereas the activity of the other enzymes is highest at harvest and decreases gradually as the apples soften in storage (Yoshioka et al., 1995). Thus, GA-I might account for the high level of activity in over-ripe fruit reported in this work. In previous reports, enzyme activity measured in crude extracts increases during fruit development, slightly decreases at harvest and is maintained at similar levels during ripening (Dick et al., 1990; Ross et al., 1994), so it has been suggested that there is no relationship between changes in the total $\beta-\mathrm{Gal}$ activities and the loss of galactose during ripening. The present results using over-ripe fruit tend to disagree with that assumption since an increase in $\beta-\mathrm{Gal}$ activity was recorded as the fruit soften. This can be explained by the nature of the material employed, since fruit with lower firmness than fruit used in other studies were employed.

The role of AFases in fruit ripening has been less studied, probably because of the absence of significant loss of arabinose during tomato ripening (Gross and Sams, 1984; Carrington et al., 1993). Total AFase activity remains constant during ripening in this species (Campbell et al., 1990; Itai et al., 2003), but closer examination reveals that, whilst the activity of two isoforms decreases during ripening, the activity of a third isoform increases (Sozzi et al., 2002).
On the other hand, arabinose is the primary neutral sugar lost during maturation of some fruit such as European pears, peaches, strawberries (Gross and Sams, 1984) and avocados (Redgwell et al., 1997b). In Japanese pear, a species with a softening behaviour similar to apples, AFase is the glycosidase that shows the highest increase in activity during ripening (Tateishi et al., 1996). During growth of Japanese pears AFase activity is highest in young small fruit and then decreases gradually as the fruit expands. During fruit enlargement, AFase activity is detected at low levels but the activity increases thereafter with ripening (Tateishi et al., 1996). Interestingly, this pattern of enzyme activity corresponds to the one obtained in our work, using 'Mondial Gala' apples. During ripening of apples, release of arabinosyl residues has been described to occur at low levels (Gross and Sams, 1984; Dick et al., 1990) and only one AFase activity was detected and found to increase during ripening (Yoshioka et al., 1995). Based on the results reported here, this enzyme may have an important role in the regulation of softening of apples at late stages of ripening. This hypothesis is supported by a comparison of several apple cultivars and 'Honeycrisp', a cultivar that maintains its crispness through long storage (Tong et al., 1999). Interestingly, the only difference observed between this cultivar and others is the maintenance of the arabinose content (Tong et al., 1999).

As stated above, apples soften without detectable depolymerisation of pectins and lack endo-PG activity. The results obtained in our work agree with these previous reports. However, an endo-PG was reported to be purified from apples (Wu et al., 1993), and activity of endo-PG was detected in ripe 'McIntosh' apples both by activity measurements and immunoblotting (Wu et al., 1993). It was suggested that previous failure to detect activity was due to low amounts of protein assayed (Wu et al., 1993). This should not be the reason for the results obtained in the present work, since activity was not detected even using up to 375 (g of total protein extracted from fruit at harvest. More work is needed to explain the detection of activity in the cited work, which contrasts with all of the literature, in order to clarify the biological mode of action of this enzyme.

The $\mathrm{pH}$ in the fruit apoplast is known to decrease during ripening (Almeida and Huber, 1999). Therefore, enzymes with an alkaline $\mathrm{pH}$ optimum, such as PME and PL are expected to be involved in the early stages of softening.

The overall degree of esterification remains at similar levels in apples during ripening (Knee, 1978b; Yoshioka et al., 1992; Klein et al., 1995). However, according to Knee (1978b) and Yoshioka et al. (1992), the degree of methylesterification decreases in the water- and CDTA-soluble fractions, whilst the insoluble fraction remains unchanged. Since the water-soluble polyuronides have a lower degree of methylation than those lost in the EDTA- and $\mathrm{HCl}$-soluble fractions, de-esterification of polyuronides is suggested to lead to their solubilisation rather than depolymerisation (Yoshioka et al., 1992), which supports the assumption that endo-PG in apples is absent or minimal. In the present work, PME activity could 
be detected in all of the developmental stages assayed, with highest activities in actively growing fruit and at fruit at harvest. The slight decrease in activity after harvest reported in this work was also observed in several other species, in which PME has been associated with ripening (Ahmed and Labavitch, 1980; Gaffe et al., 1994; Tieman and Handa, 1994) and the increase in the activity observed with the onset of commercial maturity is also in accordance with previous reports in apple (Yoshioka et al., 1992; Klein et al., 1995).

PLs have been suggested to cause depolymerisation of pectins via a $\beta$-elimination reaction (Dominguez-Puigjaner et al., 1997). Enhanced levels of enzyme activity in banana have been reported to correspond with an increase in soluble polyuronides (Marín-Rodriguez et al., 2003), but the evidence for the action of PL in the cell wall of fruit and its role during ripening is very restricted and few reports of PL activity have been published (Payasi and Sanwal, 2003). The role of PL in ripening fruit has been addressed mainly based on the observation of the mRNA accumulation of putative PL transcripts in ripening strawberries (Medina-Escobar et al., 1997) and bananas (Dominguez-Puigjaner et al., 1997; Medina-Suarez et al., 1997; Marín-Rodriguez et al., 2003). Furthermore, strawberry fruit with suppressed PL mRNA expression were significantly firmer than controls (JiménezBermúdez et al., 2002). The present work seems to be the first evidence of PL activity in apples. The results indicate that, although the highest levels of activity are observed at fruit set, activity was also detected in ripening and softening fruit, suggesting a possible role of this enzyme in the process. The detection of activity in early stages of development and ripening contrasts with the absence of activity in preclimacteric banana fruit pulp (Payasi et al., 2004). Although no depolymerisation of pectins is thought to occur in apple, this enzyme may cause subtle but important modifications on the apple cell wall and deserves further investigation.

Although no alterations in the molecular mass of the hemicellulosic fraction appears to exist in apple (Percy et al., 1997), it is known that subtle changes in the architecture and linkages of the polysaccharides that compose the cell wall of the fruit may result directly or indirectly in significant modifications in its firmness. Among the enzymes known to act on the cellulose-hemicellulose network are EGases, XTHs and expansins.

EGase activity is known to decrease during fruit growth (Bonghi et al., 1998), but it increases with ripening of several fruit, like tomato (Campbell et al., 1990; Maclachlan and Brady, 1994) Japanese pear (Yamaki and Matsuda, 1977), strawberry (Abeles and Takeda, 1990), peach (Bonghi et al., 1998) or avocado (Christoffersen et al., 1984; O’Donoghue and Huber, 1992), which suggests a role in fruit softening (Cass et al., 1990). In this study, EGase activity was high at fruit set and decreased progressively during the fruit development. This result agrees with the previous reports (Abeles and Biles, 1991) and de-emphasizes the importance of this glucanases in ripening of apples. Similarly to apples, EGase activity was not detected in ripening European pears
(Ahmed and Labavitch, 1980), grapes (Nunan et al., 2001) or muskmelons (Lester and Dunlap, 1985).

Previous reports on XET activity in apple provide contradictory results. According to Percy et al. (1996), the overall XET activity (on a fresh weight basis) is highest in young, growing apple fruit then decreases markedly towards the end of fruit expansion. According to Vincken et al. (1998) XET activity is not detected in the earlier stages of growth, and the activity increases as fruit stop growing and during cold storage. In this work, endotransglycosylase activity from XTH enzymes was observed to be low at the fruit set stage, increased to high levels when the fruit stops growing and remained high throughout ripening and softening. The results obtained tend to agree with the former authors. The apparent reduced activity of XET in growing fruit may seem surprising due to the proposed role of this enzyme in cell wall loosening. It is generally assumed that the activity of EGases is needed to generate oligosaccharides that act as acceptors for XET activity. However, although EGase activity is high at fruit set, that does not seem to reflect in high XET activities. One can speculate that, in apples, the mechanisms are not dependent. Nevertheless, the low level of XET activity at fruit set is in accordance with other work since, in persimmon, no detectable activity exists in fruit in the early stages of growing (Cutillas-Iturralde et al., 1994).

The identification of a fruit-specific and ripening-related expansin in tomato (Rose et al., 1997) and the evidence that its suppression resulted in firmer fruit with reduced breakdown of some wall components (Brummell et al., 1999) and its overexpression enhanced fruit softening (Brummell et al., 1999), suggests that expansins might contribute to cell wall disassembly and fruit softening (Rose and Bennett, 1999). Nevertheless, few studies report assays for expansin activity in fruit. An evaluation of the expansin activity in developing strawberry fruit was reported using extensibility assays (Harrison et al., 2001). The extension was greatest with extracts from ripe and over-ripe orange fruit but little or no extension was observed in fruit before the turning stage. Interestingly, in tomato, creep activity was present although at fairly low levels in extracts from stage 2 and mature green tomato fruit and induced either transient or prolonged extension, whereas the extracts from breaker fruit had negligible activity levels (Rose et al., 2000). Those results are different from those presented here. In the present work, the stressrelaxation assay is suggested to be the most specific assay for determining expansin activity, and it is clear that the highest activity occurs at fruit set and very low activity is detected in unripe expanded fruit. To the best of our knowledge, this is the first report of analysis of expansin activity during fruit development using the stress-relaxation assay. The analysis of the individual stress-relaxation profiles in specific developmental stages discloses differences in the mode of action of the expansins in distinct developmental stages. The reasons that account for these differences still require clarification but may be attributed to the involvement of different isoforms, which can act in different linkages or different regions of the cell 
wall. During apple ontogeny, at least six expansin genes are expressed with divergent and specific patterns (Wakasa et al., 2003). Different patterns of stress-relaxation spectrums were observed for the first two expansins isolated from cucumber (Cucumis sativus L.) (McQueen-Mason et al., 1992) and the authors attributed that observation to different mechanisms of action.

In summary, the overall results suggest that apple fruit have limited softening during ripening when compared with other fruit like persimmon, strawberry, kiwifruit or tomato. Therefore, one can assume that the structural integrity of the cell walls is less compromised. This assumption is supported by the results obtained in this work, since, in contrast with other species, apples have minimal endohydrolysis revealed by the fact that no detectable or low activity of endo-PG nor EGase occurs during softening. However, based on the results from PL and XET activity, hydrolytic cleavage of some linkages should not be discarded. The results obtained for exo-PG, PME, $\beta$-Gal and AFase suggest that solubilisation of pectins is determinant and occurs markedly during late softening.

Since the results of in vitro enzymatic assays may not match exactly the activity in vivo, due to methodological constraints and influence of the changes in the apoplast environment during development, the results reported here should be considered as trends in enzyme activities during apple development and ripening, but do not necessarily represent the exact measure of activity that occurs in vivo.

\section{Acknowledgements}

This work was financially supported by FCT (Fundação para a Ciência e a Tecnologia) through project POCTI/33733/99 and a personal grant to LG (BD $1133 / 2000)$

\section{Appendix A. Supplementary data}

Supplementary data associated with this article can be found, in the online version, at doi:10.1016/j.postharvbio. 2006.10.002.

\section{References}

Abeles, F.B., Biles, C.L., 1991. Cellulase activity in developing apple fruit. Sci. Hortic. 47, 77-87.

Abeles, F.B., Takeda, F., 1990. Cellulase activity and ethylene in ripening strawberry and apple fruit. Sci. Hortic. 42, 269-275.

Ahmed, A., Labavitch, J.M., 1980. Cell wall metabolism in ripening fruit. I. Changes in carbohydrate-degrading enzymes in ripening 'Bartlett' pears. Plant Physiol. 65, 1014-1016.

Almeida, D.P.F., Huber, D.J., 1999. Apoplastic pH and inorganic ion levels in tomato fruit: a potential means for regulation of cell wall metabolism during ripening. Physiol. Plant 105, 506-512.
Barnavon, L., Doco, T., Terrier, N., Ageorges, A., Tomieu, C., Pellerin, P., 2000. Analysis of cell wall neutral sugar composition. $\beta$-galactosidase activity and a related cDNA clone throughout the development of Vitis vinifera grape berries. Plant Physiol. Biochem. 38, 289-300.

Bartley, I.M., 1974. Beta-galactosidase activity in ripening apples. Phytochemistry 13, 2107-2111.

Bartley, I.M., 1976. Changes in the glucans of ripening apples. Phytochemistry $15,625-626$.

Bartley, I.M., 1978. Exo-polygalacturonase of apple. Phytochemistry 17, 213-216.

Bonghi, C., Ferrarese, L., Ruperti, B., Tonutti, P., Ramina, A., 1998. EndoB-1,4-glucanases are involved in peach fruit growth and ripening, and regulated by ethylene. Physiol. Plant 102, 346-352.

Bradford, M.M., 1976. A rapid and sensitive method for the quantitation of microgram quantities of protein utilizing the principle of protein-dye binding. Anal. Biochem. 72, 248-254.

Brett, C., Waldron, K. (Eds.), 1996. Physiology and Biochemistry of Plant Cell Walls, second ed. Chapman \& Hall, London, UK, p. 255.

Brummell, D.A., Harpster, M.H., Civello, P.M., Palys, J.M., Bennett, A.B., Dunsmuir, P., 1999. Modification of expansin protein abundance in tomato fruit alters softening and cell wall polymer metabolism during ripening. Plant Cell 11, 2203-2216.

Brummell, D.A., Labavitch, J.M., 1997. Effect of antisense suppression of endopolygalacturonase activity on polyuronide molecular weight in ripening tomato fruit and fruit homogenates. Plant Physiol. 115, 717-725.

Campbell, A.D., Huysamer, M., Stotz, H.U., Greve, L.C., Labavitch, J.M., 1990. Comparison of ripening processes in intact tomato fruit and excised pericarp discs. Plant Physiol. 94, 1582-1589.

Carrington, C., Greve, L.C., Labavitch, J.M., 1993. Cell wall metabolism in ripening fruit. VI. Effect of the antisense polygalacturonase gene on cell wall changes accompanying ripening in transgenic tomatoes. Plant Physiol. 103, 429-434.

Cass, L.G., Kirven, K.A., Christoffersen, R.E., 1990. Isolation and characterization of a cellulase gene family member expressed during avocado fruit ripening. Mol. Gen. Genet. 223, 76-86.

Christoffersen, R.E., Tucker, M.L., Laties, G.G., 1984. Cellulase gene expression in ripening avocado fruit: the accumulation of cellulase mRNA and protein as demonstrated by cDNA hybridization and immunodetection. Plant Mol. Biol. 3, 385-391.

Collmer, A., Ried, J.L., Mount, M.S., 1988. Assay methods for pectic enzymes. Methods Enzymol. 161, 329-335.

Cosgrove, D.J., 1989. Characterization of long-term extension of isolated cell walls from growing cucumber hypocotyls. Planta 177, 121-130.

Cosgrove, D.J., 1996. Plant cell enlargement and the action of expansins. Bioassays 18, 533-540.

Cutillas-Iturralde, A., Zarra, I., Fry, S.C., Lorences, E.P., 1994. Implication of persimmon fruit hemicellulose metabolism in the softening process. Importance of xyloglucan endotransglycosylase. Physiol. Plant 91, 169-176.

Cutillas-Iturralde, A., Zarra, I., Lorences, E.P., 1993. Metabolism of cell wall polysaccharides from persimmon fruit. Pectin solubilization during fruit ripening occurs in apparent absence of polygalacturonase activity. Physiol. Plant 89, 369-375.

Deutscher, M.P. (Ed.), 1990. Guide to Protein Purification. Academic Press Inc., London UK, Methods Enzymol. 182, 894 pp.

Dick, A.J., Opoku-Gyamfua, A., deMarco, A.C., 1990. Glycosidases of apple fruit: a multi-functional $\beta$-galactosidase. Physiol. Plant 80 , $250-256$.

Dominguez-Puigjaner, E., LLop, I., Vendrell, M., Prat, S., 1997. A cDNA clone highly expressed in ripe banana fruit shows homology to pectate lyases. Plant Physiol. 114, 1071-1076.

Durbin, M.L., Lewis, L.N., 1988. Cellulases in Phaseolus vulgaris. Methods Enzymol. 160, 342-351.

Fry, S.C., 1997. Novel 'dot-blot' assays for glycosyltransferases and glycosylhydrolases: optimization for xyloglucan endotransglycosylase activity. Plant J. 11, 1141-1150. 
Gaffe, J., Tieman, D.M., Handa, A.K., 1994. Pectin methylesterase isoforms in tomato (Lycopersicon esculentum) tissues. Effects of expression of a pectin methylesterase antisense gene. Plant Physiol. 105, 199-203.

Gillaspy, G., Ben-David, H., Gruissem, W., 1993. Fruit: a developmental perspective. Plant Cell 5, 1439-1451.

Gross, K.C., 1982. A rapid and sensitive spectrophotometric method for assaying polygalacturonase using 2-cyanoacetamide. HortScience 17, 933-934.

Gross, K.C., Sams, C.E., 1984. Changes in cell wall neutral sugar composition during fruit ripening: a species survey. Phytochemistry 23, 2457-2461.

Hagerman, A.E., Austin, P.J., 1986. Continuous spectrophotometric assay for plant pectin methyl esterase. J. Agric. Food Chem. 34, 440-444.

Harrison, E.P., McQueen-Mason, S.J., Manning, K., 2001. Expression of six expansin genes in relation to extension activity in developing strawberry fruit. J. Exp. Bot. 52, 1437-1446.

Huber, D.J., 1983. The role of cell wall hydrolysis in fruit softening. Hortic. Rev. 5, 169-219.

Huber, D.J., O’Donoghue, E.M., 1993. Polyuronides in avocado (Persea americana) and tomato (Lycopersicon esculentum) fruit exhibit markedly different patterns of molecular weight downshifts during ripening. Plant Physiol. 102, 473-480.

Itai, A., Ishihara, K., Bewley, J.D., 2003. Characterization of expression, and cloning, of beta-D-xylosidase and alpha-L-arabinofuranosidase in developing and ripening tomato (Lycopersicon esculentum Mill) fruit. J. Exp. Bot. 54, 2615-2622.

Jiménez-Bermúdez, S., Redondo-Nevado, J., Muñoz-Blanco, J., Caballero, J.L., López-Aranda, J.M., Valpuesta, V., Pliego-Alfaro, F., Quesada, M.A., Mercado, J.A., 2002. Manipulation of strawberry fruit softening by antisense expression of a pectate lyase gene. Plant Physiol. 128, 751-759.

Johnston, J.W., Hewett, E.W., Banks, N.H., Harker, F.R., Hertog, M.L.A.T.M., 2001. Physical change in apple texture with fruit temperature: effects of cultivar and time in storage. Postharvest Biol. Technol. $23,13-21$.

Johnston, J.W., Hewett, E.W., Hertog, M.L.A.T.M., 2002. Postharvest softening of apple (Malus domestica) fruit: a review. N. Z. J. Crop Hortic. Sci. 30, 145-160.

Klein, J.D., Hanzon, J., Irwin, P.L., Shalom, N.B., Lurie, S., 1995. Pectin esterase activity and pectin methyl esterification in heated Golden Delicious apples. Phytochemistry 39, 491-494.

Knee, M., 1978a. Properties of polygalacturonate and cell cohesion in apple fruit cortical tissue. Phytochemistry 17, 1257-1260.

Knee, M., 1978b. Metabolism of polymethylgalacturonate in apple fruit cortival tissue during ripening. Phytochemistry 17, 1261-1264.

Lay-Yee, M., DellaPenna, D., Ross, G.S., 1990. Changes in mRNA and protein during fruit ripening in apple fruit (Malus $\times$ domestica Borkh. cv 'Golden Delicious'). Plant Physiol. 94, 850-853.

Lester, G.E., Dunlap, J.R., 1985. Physiological changes during development and ripening of 'Perlita' muskmelon fruit. Sci. Hortic. 2, 323-331.

Maclachlan, G., Brady, C., 1994. Endo-1,4- $\beta$-glucanase, xyloglucanase, and xyloglucan endo-transglycosylase activities versus potential substrates in ripening tomatoes. Plant Physiol. 105, 965-974.

MacRae, E., Redgwell, R.J., 1992. Softening of kiwifruit. Postharvest News Information 3, 49N-52N.

Marín-Rodriguez, M.C., Smith, D.L., Manning, K., Orchard, J., Seymour, G.B., 2003. Pectate lyase gene expression and enzyme activity in ripening banana fruit. Plant Mol. Biol. 51, 851-857.

McGuire, R.G., 1992. Reporting of objective colour measurement. HortScience 27, 1254-1255.

McQueen-Mason, S., Durachko, D.M., Cosgrove, D.J., 1992. Two endogenous proteins that induce cell wall extension in plants. Plant Cell 4 , 1425-1433.

Medina-Escobar, N., Cardenas, J., Moyano, E., Caballero, J.L., MunozBlanco, J., 1997. Cloning, molecular characterization and expression pattern of a strawberry ripening-specific cDNA with sequence homology to pectate lyase from higher plants. Plant Mol. Biol. 34, 867-877.
Medina-Suarez, R., Manning, K., Fletcher, J., Aked, J., Bird, C.R., Seymour, G.B., 1997. Gene expression in the pulp of ripening bananas. Twodimensional sodium dodecyl sulfate-polyacrylamide gel electrophoresis of in vitro translation products and cDNA cloning of 25 different ripening-related mRNAs. Plant Physiol. 115, 453-461.

Nunan, K.J., Davies, C., Robinson, S.P., Fincher, G.B., 2001. Expression patterns of cell wall-modifying enzymes during grape berry development. Planta 214, 257-264.

O’Donoghue, E.M., Huber, D.J., 1992. Modification of matrix polysaccharides during avocado (Persea americana) fruit ripening: an assessment of the role of Cx-cellulase. Physiol. Plant 86, 33-42.

Orr, G., Brady, C.J., 1993. Relationship of endopolygalacturonase activity to fruit softening in a freestone peach. Postharvest Biol. Technol. 3, $121-130$.

Payasi, A., Misra, P.C., Sanwal, G.G., 2004. Effect of phytohormones on pectate lyase activity in ripening Musa acuminata. Plant Physiol. Biochem. 42, 861-865.

Payasi, A., Sanwal, G.G., 2003. Pectate lyase activity during ripening of banana fruit. Phytochemistry 63, 243-248.

Peña, M.J., Carpita, N.C., 2004. Loss of highly branched arabinans and debranching of rhamnogalacturonan I accompany loss of firm texture and cell separation during prolonged storage of apple. Plant Physiol. 135, 1305-1313.

Percy, A.E., Melton, L.D., Jameson, P.E., 1997. Xyloglucan and hemicelluloses in the cell wall during apple fruit development and ripening. Plant Sci. 125, 31-39.

Percy, A.E., O’Brien, I.E.W., Jameson, P.E., Melton, L.D., MacRae, E.A., Redgwell, R.J., 1996. Xyloglucan endotransglycosylase activity during fruit development and ripening of apple and kiwifruit. Physiol. Plant 96, 43-50.

Pilatzke-Wunderlich, I., Nessler, C.L., 2001. Expression and activity of cell-wall-degrading enzymes in the latex of opium poppy, Papaver somniferum L. Plant Mol. Biol. 45, 567-576.

Pressey, R., 1983. $\beta$-galactosidase in ripening tomatoes. Plant Physiol. 71, $132-135$.

Redgwell, R.J., MacRae, E., Hallett, I., Fisher, M., Perry, J., Harker, R., 1997a. In vivo and in vitro swelling of cell walls during fruit ripening. Planta 203, 162-173.

Redgwell, R.J., Fischer, M., Kendal, E., MacRae, E.A., 1997b. Galactose loss and fruit ripening: high-molecular-weight arabinogalactans in the pectic polysaccharides of fruit cell walls. Planta 203, 174-181.

Rose, J.K., Cosgrove, D.J., Albersheim, P., Darvill, A.G., Bennett, A.B., 2000. Detection of expansin proteins and activity during tomato fruit ontogeny. Plant Physiol. 123, 1583-1592.

Rose, J.K., Lee, H.H., Bennett, A.B., 1997. Expression of a divergent expansin gene is fruit-specific and ripening-regulated. Proc. Natl. Acad. Sci. U.S.A. 94, 5955-5960.

Rose, J.K.C., Bennett, A.B., 1999. Cooperative disassembly of the cellulose-xyloglucan network of plant cell walls: parallels between cell expansion and fruit ripening. Trends Plant Sci. 4, 176-183.

Ross, G.S., Wegrzyn, T., MacRae, E.A., Redgwell, R., 1994. Apple $\beta$ galactosidase. Activity against cell wall polysaccharides and characterization of a related cDNA clone. Plant Physiol. 106, 521-528.

Sakurai, N., Nevins, D.J., 1997. Relationship between fruit softening and wall polysaccharides in avocado (Persea americana Mill) mesocarp tissues. Plant Cell Physiol. 38, 603-610.

Sakurai, N., Nevins, J.J., 1993. Changes in the physical properties and cell wall polysaccharides on tomato (Lycopersicon esculentum) pericarp tissue. Physiol. Plant 89, 681-686.

Seymour, G.B., Colquhoun, I.J., Dupont, M.S., Parsley, K.R., Selvendran, R.R., 1990. Composition and structural features of cell wall polysaccharides from tomato fruit. Phytochemisty 29, 725-731.

Siddiqui, S., Brackmann, A., Streif, J., Bangerth, F., 1996. Controlled atmosphere storage of apples: cell wall composition and fruit softening. J. Hortic. Sci. 71, 613-620.

Smith, C.J.S., Watson, C.F., Ray, J., Bird, C.R., Morris, P.C., Schuch, W., Grierson, D., 1988. Antisense RNA inhibition of polygalactur- 
onase gene expression in transgenic tomatoes. Nature 334, 724726.

Smith, D.L., Abbott, J.A., Gross, K.C., 2002. Down-regulation of tomato $\beta$ galactosidase 4 results in decreased fruit softening. Plant Physiol. 129, 1755-1762.

Sozzi, G.O., Greve, C., Prody, G.A., Labavitch, J.M., 2002. Gibberellic acid, synthetic auxins, and ethylene differentially modulate $\alpha$ $\mathrm{L}$-arabinofuranosidase activities in antisense 1-aminocyclopropane-1carboxylic acid synthase tomato pericarp discs. Plant Physiol. 129, 1330-1340.

Tagawa, K., Kaji, A., 1988. Polygalacturonase from Corticium rolfsii. Methods Enzymol. 161, 361-366.

Tateishi, A., Kanayama, Y., Yamaki, S., 1996. Alpha-L-arabinofuranosidase from cell walls of Japanese pear fruit. Phytochemistry 42, 295-299.

Tieman, D.M., Handa, A.K., 1994. Reduction in pectin methylesterase activity modifies tissue integrity and cation levels in ripening tomato (Lycopersicon esculentum Mill) fruit. Plant Physiol. 106, 429-436.

Tong, C., Krueger, D., Vickers, Z., Bedford, D., Luby, J., El-Shiekh, A., Schackel, K., Ahmadi, H., 1999. Comparison of softening-related changes during storage of 'Honeycrisp' apple, it parents, and 'Delicious'. J. Am. Soc. Hortic. Sci. 124, 407-415.
Vincken, J.P., Zabotina, O.A., Beldman, G., Voragen, A.G.J., 1998. Xyloglucan endotransglycosylase activity in apples is ripening-related: implications for fruit juice processing. J. Sci. Food Agric. 78, 46-52.

Wakasa, Y., Hatsuyama, Y., Takahashi, A., Sato, T., Niizeki, M., Harada, T., 2003. Divergent expression of six expansin genes during apple fruit ontogeny. Euro. J. Hortic. Sci. 68, 253-259.

Weissbach, A., Hurwitz, J., 1959. The formation of 2-keto-3-deoxyheptonic acid in extracts of Escherichia coli. J. Biol. Chem. 234, 705-709.

Wu, Q., Szakacs-Dobozi, M., Hemmat, M., Hrazdina, G., 1993. Endopolygalacturonase in apples (Malus domestica) and its expression during fruit ripening. Plant Physiol. 102, 219-225.

Yamaki, S., Matsuda, K., 1977. Changes in the activities of some cell wall degrading enzymes during development and ripening of Japanese pear fruit (Pyrus serotina Rehder var Culta). Plant Cell Physiol. 18, 81-93.

Yoshioka, H., Aoba, K., Kashimura, Y., 1992. Molecular weight and degree of methoxylation in cell wall polyuronide during softening in pear and apple fruit. J. Am. Soc. Hortic. Sci. 117, 600-606.

Yoshioka, H., Kashimura, Y., Kaneko, K., 1995. $\beta$-D-galactosidase and $\alpha-$ L-arabinofuranosidase activities during the softening of apples. J. Jpn. Soc. Hortic. Sci. 63, 871-878. 